\title{
Improving Land Use Planning through the Evaluation of Ecosystem Services: One Case Study of Quyang County
}

\author{
Lin Liu, ${ }^{1}$ Yapeng Zhou $\mathbb{D D}^{2,3}$ Haikui Yin ${ }^{2},{ }^{4}$ Ruiqiang Zhang, ${ }^{5}$ Ying Ma, ${ }^{2,3}$ Guijun Zhang, ${ }^{2,3}$ \\ Pengfei Zhao, ${ }^{2,3}$ and Jinxiong Feng ${ }^{2,3}$ \\ ${ }^{1}$ Land Resources and Urban Planning Institute, Hebei GEO University, Shijiazhuang 050031, China \\ ${ }^{2}$ College of Land Resources, Hebei Agricultural University, Baoding 071001, China \\ ${ }^{3}$ Field Observation Base of Mine Ecology Environment in Baoding, Hebei, Baoding 071001, China \\ ${ }^{4}$ School of Water Conservancy and Hydroelectric Power, Hebei University of Engineering, Handan 056038, China \\ ${ }^{5}$ College of Humanities and Social Sciences, Hebei Agricultural University, Baoding 071001, China
}

Correspondence should be addressed to Yapeng Zhou; zhouyp@hebau.edu.cn and Haikui Yin; yinhaikui@hebeu.edu.cn

Received 26 May 2021; Accepted 9 August 2021; Published 27 August 2021

Academic Editor: Jun Yang

Copyright (c) 2021 Lin Liu et al. This is an open access article distributed under the Creative Commons Attribution License, which permits unrestricted use, distribution, and reproduction in any medium, provided the original work is properly cited.

\begin{abstract}
Competition for land is increasing as demand for multiple land uses and ecosystem services rises. Land regulation of the principles of landscape ecology is necessary to develop more sustainable approaches to land use planning. The research evaluated the present land patterns and determined best practices for its regulation of Dongwang Township in Quyang County, located in the Taihang Mountain area of Hebei Province, China. The research used the landscape ecology theory to construct an index system for landscape pattern analysis based on the GIS and Fragstats 3.3 software. In this study, we examined the specific reasons that landscape ecology is superior to traditional methods in land consolidation planning and design, which is conducive to the comprehensive development of land ecological benefits. Landscape ecological planning can effectively reduce landscape fragmentation and improve intensive management. The result found that the descending order of the Shannon index was current landscape, landscape ecological planning, and traditional planning. Landscape ecological planning could protect the natural diversity than traditional planning. Landscape ecological planning enables the creation of long corridors, with higher densities and connectivity and lower average corridor widths than traditional planning. Besides, it can improve ecological service function values in the study area to varying degrees, thus discouraging residents from limiting themselves to grain production. This research has great potential to improve the visibility of ecosystem services in local land use planning and, thus, to improve the ecological functioning of future landscapes.
\end{abstract}

\section{Introduction}

Competition for land is increasing as demand for multiple land uses and ecosystem services rises. The quantity and quality of cultivated land are declining, which seriously threaten food security and ecological security [1-3]. Land consolidation planning helps alleviate the strained relations between man and land, especially in safeguarding the construction land required in the context of economic development. Land regulation primarily originated in European countries in the Middle Ages. However, there is some evidence that land regulation began earlier in countries such as Germany, France, and Russia $[4,5]$. In general, the history of land regulation involved three stages. The first stage extended from the middle of the $16^{\text {th }}$ century to the end of the $19^{\text {th }}$ century and was defined by organized and planned land consolidation, adjustments of ownership, and improvement of agricultural production conditions to carry out simple land renovations. The second stage stretched from the beginning of the $20^{\text {th }}$ century to the $1950 \mathrm{~s}$; with the emergence of industrialization, land renovation began to revolve around urban construction and industrial development, which is a specific stage of land renovation. The third stage occurred in the 1960s, when land renovation 
began to be geared toward promoting regional economic development, narrowing the gap between urban and rural areas, increasing incomes, and protecting and improving the ecological environment. It was a more comprehensive stage of land renovation, and the integration of landscape ecology would play an important role in the improvement of Europe's ecology $[6,7]$.

Meanwhile, the history of land regulation in China can be traced back to the Jingtian system in the pre-Qin period [8]. Since the Qin and Han dynasties [9-11], China has notably been home to a state-owned land manor and farmland system, to name but a few of its approaches to land use. Although land renovation has been carried out in various forms since the founding of the People's Republic of China, the nation lagged in generally accepted theoretical and technical aspects of land renovation until the formulation of the Land Management Law in the 1990s, which promotes China's land renovation activities to a new level [12]. At present, the research on land consolidation in China mainly focuses on land suitability evaluation; however, methods for land regulation project planning and design, comprehensive benefit analyses of land, and making land consolidation planning are greater research potential [13-18].

Landscape ecological planning and design uses landscape ecology theory and its related methods. At present, several main approaches to ecological planning and landscape design are employed globally. One of these approaches is the thousand-layer cake planning model [19], which was presented by American ecological landscape architect McHarg. This approach involves calculating the ecological suitability of natural resources in a regional landscape ecosystem to optimize its landscape utilization and regional development direction. Another approach is the one-compartment model of ecological land use [20]; proposed by American ecologist Odum, this model, based on system science theory, takes the regional landscape ecosystem health as optimal goals, discusses the regulation mechanism of natural and social-economic factors, and yields an allocation decision. Finally, the differentiated land-use model, which was proposed by German biologist Haber [21], is mainly suitable for the overall planning of landscapes in high-density areas and involves an evaluation of the overall effect of a proposed landscape plan by environmental diagnostic and pattern analysis indices.

In the late 20th century, theories and principles of landscape ecology were integrated with traditional approaches to landscape planning. The integrated development is largely attributed to Forman's 1995 book Landscape Ecology, which summarizes the methods of landscape ecological pattern optimization [22]. More specifically, as populations, food demand, and environmental pollution increased during the mid to late $20^{\text {th }}$ century, many nations such as Germany and the Netherlands turned to land as their main research object, thereby encouraging interest in landscape ecology. At the same time, the International Landscape Ecology Society (IALE) was formally established at the Sixth International Symposium on Landscape Ecology in Czechoslovakia in 1982; this marked a new stage in the development of landscape ecology [23]. The study of landscape ecology has gradually prevailed from European countries throughout the world [24]. Huang and Liu introduced landscape ecology to China in 1981 [25, 26]. Although the implementation of landscape ecology principles in China lagged to Europe and America, the application was prompted rapidly. Meanwhile, outside of China, in 1984, Naveh and Lieberman published a notable landscape ecology monograph, Landscape Ecology: Theory and Application, which was the first monograph in the field. The first National Colloquium on Landscape Ecology in China was held in October 1989 in Shenyang; this opened a new chapter for the study of landscape ecology in China. In 1992, the Committee of Landscape Ecology of the Chinese Society of Ecology was established; since then, the study of landscape ecology has progressed greatly in China [27]. During the 10 years since the establishment of the Professional Committee on Landscape Ecology, Chinese scholars have published a series of monographs on landscape ecology.

Today, it is clear that land renovation must include a series of biological and engineering measures, which will inevitably break the original state of land resources in a certain area and directly and indirectly benefit and harm regional environmental factors such as water resources, soil, vegetation, and biology and their ecological processes [28-31]. The sustainability of land resources can also be seriously affected if inappropriate remediation damages ecosystems and reduces land productivity. To improve the environment of agricultural areas and the land production capacity, and preserve the sustainable use of regional land, landscape ecological planning and design should be normalized in the planning layout of land renovation projects for diverse design to protect and strengthen the region's fragile and simple ecosystems [32-34].

There may be several concrete objectives of landscape ecological planning for land renovation. These include increasing the area of cultivated land, expanding the scale of farmers' land management, enhancing the potential of land production and farmer competitiveness through the renovation of broken farmland and land ownership, improving rural life, ecology, environmental, and landscape functions, while also constructing green infrastructure for urban-rural integration that protects biodiversity, prevents rural pollution, protects natural resources, maintains and improves rural ecological landscape service functions, and realizes land management at different levels, and realizing the integrity of ecological function, that is, coupling the land-use system with its external environment to realize the entire function. More specifically, the land use mode and ditch road design can be determined by considering the topography, climate, hydrological condition, water resource condition, social condition, and economic condition; improving natural function compatibility states that the planning and design of the land renovation of agricultural ecosystems should apply the principles of landscape heterogeneity and ecological diversity to enhance the ecological functions of landscape patch in line with the requirements of agricultural production. 


\section{Landscape Ecological Planning and Design}

2.1. Landscape Ecological Pattern Adjustment. Land renovation is the process of optimizing an area's current land use pattern. Guided by the theory of landscape ecology, land renovation follows the sustainable development principles of protecting and improving the ecological environment. Notably, it involves the comprehensive adjustment and reconstruction of the landscape's spatial structure and patterns; for example, modifications include laying out roads, drainage and irrigation networks, crops, farmland structures, shelterbelt systems, and land units in ways that construct harmonious spatial structures, stabilize ecosystems, and ultimately realize the goal of the sustainable use of land resources.

2.2. Landscape Ecological Patch Planning and Design. The types of landscape ecological patches in the study area included irrigated land, dry land, garden land, woodland, residential land, funeral land, sandy land, bare land, and wasteland. Based on the characteristics of the land renovation project, some forestland with high ecological service value in the study area was reserved, and some bare land near the forest land in the east of the study area was transformed into forest land to increase the area's ecological service value.

Our analysis of the landscape pattern index revealed that our area had a high number of cultivated landscape patches, a small average patch area, and high landscape fragmentation. Notably, the latter weakens biodiversity and land production capacity. The farmland landscape patches (where wheat and corn are mainly planted) should therefore be rectangular, in line with the topography and distribution of water resources in the Taihang Mountain front plain area. The width and length of the field were $200-300 \mathrm{~m}$ and $400-600 \mathrm{~m}$, respectively, and the average patch area was $7-10 \mathrm{hm}^{2}$. Meanwhile, land leveling in the study area exhibited the mechanical local leveling scheme; adapted land leveling should not reduce soil fertility and should maintain the fertility of the thin soil layer.

\subsection{Landscape Ecological Corridor Planning and Design}

2.3.1. Ditch Corridor. The analysis on the landscape pattern revealed that the number of ditch corridors in the study area was small, their total length low, and their width uneven; moreover, the ditch corridors were in a state of abandonment or semiwaste, which precludes irrigation and drainage. During the planning and design of the irrigation and drainage corridor, the water conveyance channel was created according to the traditional planning and design to save cultivated land; more specifically, an underground lowpressure water conveyance PVC pipeline was adopted. Meanwhile, as per the design plan of our area's cultivated landscape patch unit, the drainage ditch was arranged reasonably; it effectively formed the channel corridor network, kept the water circulation unblocked, reduced the probability of flood disaster, and ensured the reasonable circulation of water resources in the region.
Moreover, the landscape ecological design of the drainage ditch was based on the drainage area. Once every 10 years, the daily rainstorm amount $(210 \mathrm{~mm})$ in the dry farming area and the daily rainstorm amount $(210 \mathrm{~mm})$ in the paddy fields are discharged to the related depths of crop flooding. According to the Design Code for Irrigation and Drainage Engineering (GB50288-99), the widths of an agricultural and bucket ditch are designed to be 2.5 and $4.2 \mathrm{~m}$, respectively. We were concerned primarily with our drainage ditch's soil quality and trapezoidal structure. The slope of the drainage ditch was designed to be gentle; the Dougou slope ratio was $1: 1.5$ and the Nonggou slope ratio was $1: 1$, which were selected to enhance the area's ability to serve as a habitat for its resident species. Besides, to protect the drainage ditch slope and provide this green habitat, the turf was planted in the drainage ditch slope.

2.3.2. Road Corridor of Farmland. Our analysis of the landscape pattern index showed that the field and production were messy and narrow; moreover, their pavement quality and connectivity were poor, which complicates vehicle transportation and the underground operations of farmland machinery. Notably, the mechanization of cultivated land patches was also seriously affected. After renovation, the road corridors formed a network connection system, with their layout in alignment with the designs of each patch. Meanwhile, the design of the farmland roads was mainly based on traditional approaches to ecological modification and construction fused with ecological engineering. Compared with traditional planning approaches, the landscape ecological design of the farmland road corridor reduced its width; the width of the field road was reduced to $4 \mathrm{~m}$, and the width of the production road was set at $2.5 \mathrm{~m}$; the cultivated land was meant to enable the movements of vehicles and farmland machinery. Moreover, the road corridors were designed to include an ecological hole with a diameter of $20 \mathrm{~cm}$ every $100 \mathrm{~m}$ below the roadbed to account for the movements of small animals in the field, fostering their survival and habitat.

2.3.3. Shelterbelt Corridor of Farmland. Our analysis of the landscape pattern index also made clear that there were only a few farmland shelterbelt corridors in our area. Ultimately, such a small number cannot form the perfect farmland shelterbelt system necessary for protecting the ecological environment. In response, the farmland shelterbelt project plans propose modifying the forest belt according to local conditions by adopting the permeable shelterbelt. The farmland shelterbelt was mainly arranged in line with existing standards along the drainage ditch and farmland road; a single arbor road layout model was adopted. The tree species selected was a fast-growing poplar suitable for the local climate and soil conditions; meanwhile, plant spacing was set at $2 \mathrm{~m}$. It is helpful to note that the farmland shelterbelt is not only an important means of improving the local microclimate, water, wind, and sand conservation but also an effective way of increasing land use space and biodiversity. 


\section{Material and Methods}

3.1. Overview of the Study Area. The study area was located in the west of the North China Plain, along the eastern foot of Taihang Mountain (Figure 1). The geographical coordinates of the area are $38^{\circ} 35^{\prime \prime}-38^{\circ} 38^{\prime} 15^{\prime \prime} \mathrm{N}$ and $114^{\circ} 48^{\prime} 08^{\prime \prime} \mathrm{E}-114^{\circ} 52^{\prime} 31^{\prime \prime} \mathrm{E}$. In the warm, temperate, and continental monsoon climate, the average annual precipitation is $571 \mathrm{~mm}$, which is concentrated mainly between July and September and accounts for $64.4 \%$ of the annual precipitation. Meanwhile, the annual evaporation is $1,230 \mathrm{~mm}$, which is more than 2.15 times higher than the precipitation. The annual mean temperature is $11^{\circ} \mathrm{C}$. The average annual wind speed is $2.3 \mathrm{~m} / \mathrm{s}$, with the maximum wind speed occurring in spring, at $2.9 \mathrm{~m} / \mathrm{s}$. Besides, the permafrost depth is usually between 30 and $55 \mathrm{~cm}$ [35]. The region also experiences approximately $2,600 \mathrm{~h}$ of sunshine a year, and its frost-free period extends for 190 days. Notably, the research area belongs to the flood alluvial plain in front of Taihang Mountain. High in the northwest and low in the southeast, the area's surface slope falls between $1 / 1500$ and 1/2000. Overall, however, the terrain is flat, with only gentle slopes and depressions. Meanwhile, the groundwater resources in the study area were divided into deep and shallow freshwater. Deep groundwater is not easy to access, and supply difficulties can occur. Shallow freshwater is the main resource of current industrial and agricultural production and domestic water use. Meanwhile, the main recharge modes include rainfall infiltration, backward supply, channel infiltration, and irrigation field infiltration.

The study area was located along the ancient road of the Tang River, where the soil is mainly flooded alluvial cinnamon, the soil surface is sandy loam, and the tillage layer nutrient content is low. Notably, the soil is characterized by fertilizer leakage, good permeability, $0.87 \%$ organic matter, $0.055 \%$ nitrogen, $29 \mathrm{mg} / \mathrm{kg}$ of alkali-hydrolyzed nitrogen, $3 \mathrm{mg} / \mathrm{kg}$ of kinetic phosphorus, and $88 \mathrm{mg} / \mathrm{kg}$ of available potassium. These conditions are suitable for planting winter wheat, summer corn, and peanuts, to name but a few consequential crops. Generally, the main cash crops include wheat, barley, corn, strawberry, soybean, black bean, mung bean, cotton, sesame, and peanut. Meanwhile, herbaceous plants include Eragrostis pilosa, Digitaria sanguinalis (L.) Scop., Chloris virgata Sw., Xanthium sibiricum, Taraxacum mongolicum Hand.-Mazz., Dendranthema indicum, Atractylodes macrocephala Koidz, and Rehmannia glutinosa. Trees belong to the Salix, Populus, Ulmus, Sophora, Toona, Amygdalus, Pyrus, Ziziphus, and Malus genera.

The total area of cultivated land is $920.8073 \mathrm{hm}^{2}$ across North Xinshu, West Xinshu, South Xinshu, and Zhicao villages. The total population is 10,482 , the cultivated land per-capita is $0.0913 \mathrm{hm}^{2}$, the annual per-capita net income is 962 yuan, the wheat yield is $5,250 \mathrm{~kg} / \mathrm{hm}^{2}$, and the corn yield is $6,000 \mathrm{~kg} / \mathrm{hm}^{2}$. Local farmers are engaged mainly in agricultural production, owing to the poor natural conditions, a low degree of intensification of agricultural production, low output efficiency and per-capita output value, low per-capita net income, and the abundance of labor and land resources, which offer great potential for remediation.

3.2. Research Methods. The analysis performed using software included image vectorization, landscape pattern index calculation, and ecosystem service value calculation. The MapGIS software was used to plan and design the land regulation in the study area, and ArcGIS software was used to convert the image into a grid map. The landscape index included three indices: patch characteristics, landscape diversity, and corridor characteristics. The landscape index included the patch index, landscape diversity index, and corridor characteristic index. The landscape diversity index included the Shannon diversity index, evenness index, and dominance index. The corridor characteristic index included the average corridor width index, corridor density index, corridor fractal dimension, and corridor connectivity index.

Costanza's [36] adapted formula of the ecosystem service value was used to calculate the service value of the terrestrial ecosystem in the study area. The formula is as follows:

$$
\mathrm{ESV}=\sum_{i=1}^{6}\left(A_{i} \times \mathrm{VC}_{i}\right)
$$

where ESV represents the total value of ecosystem services in one year, $A_{i}$ represents the distribution area of $i$ land-use type in the study area $\left(\mathrm{hm}^{2}\right)$, and $\mathrm{VC}_{i}$ represents the ecosystem service value (Yuan/hm $\left.{ }^{2} \cdot \mathrm{a}\right)$ of $i$ land-use type.

This study sought to uncover the benefits of different approaches to land regulation in this area to optimize land regulation theory, planning, and design by analyzing the landscape pattern analysis index and ecological service value across traditional land regulation and landscape ecological planning.

\section{Comparison and Analysis of Results}

\subsection{Current Situation of the Landscape Pattern}

4.1.1. Landscape Structure. The landscape structure of the study area (Figure 2 and Table 1) was obtained using the 1: 1000 land-use status map as the base map. The total landscape area of the village of North Xingshu in Dongwang Township in this study was $1,522.7820 \mathrm{hm}^{2}$ and included 13 different landscape types (Table 2). As indicated above, this study used MapGIS software to process the land-use status map of the study area and ArcGIS software to convert the image into a grid map before introducing it into Fragstats 3.3 to calculate the various landscape indexes. Because farmland roads, farmland shelterbelts, ridges, and some ditches emerged as linear features, these parts of the area were merged into local categories.

4.1.2. Patch Characteristics Index. Notably, Table 2 demonstrates that the spatial structures of the study area's landscape elements differ significantly; in particular, a large number of patches and relatively higher patch density were 


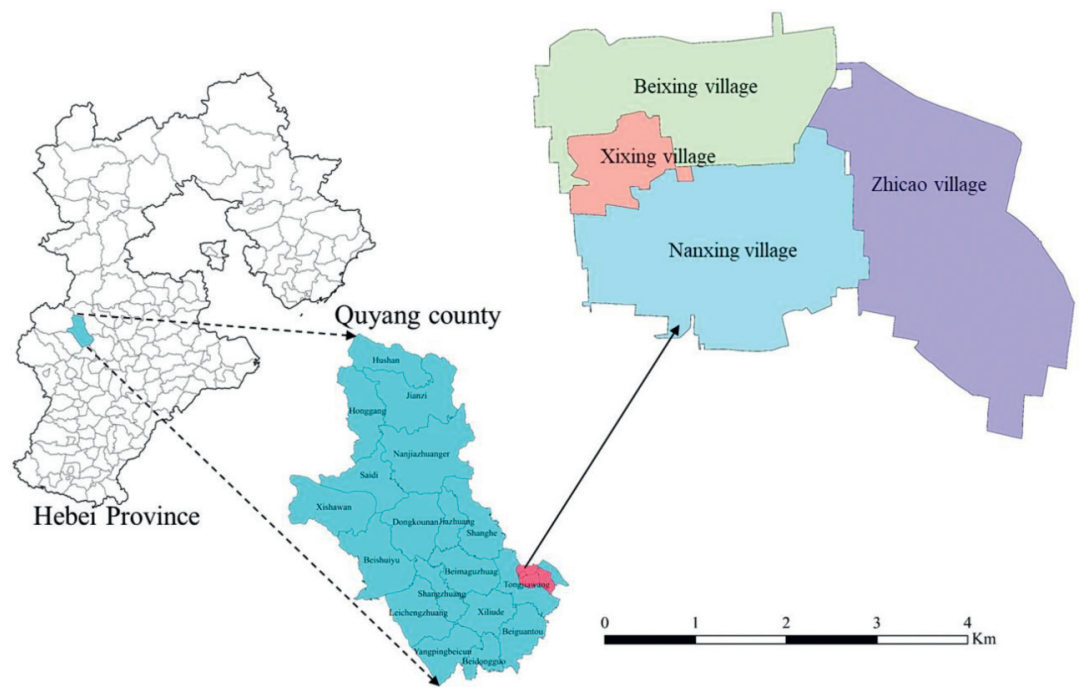

Figure 1: Location of the study area.

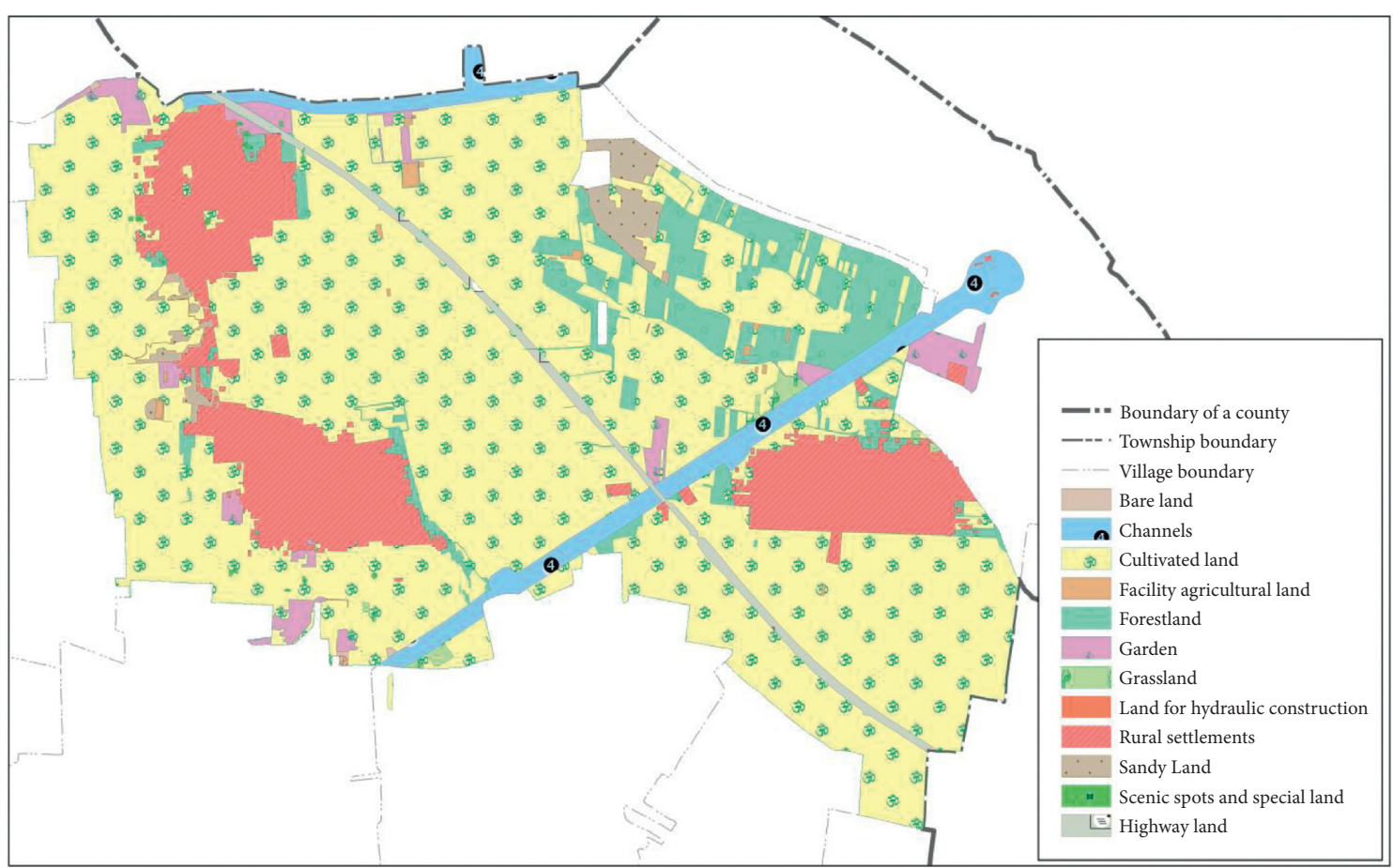

Figure 2: The map of land uses on Beixingshu village, Dongwang Township, Quyang County, and Baoding City, Hebei Province in 2017.

present in the cultivated land, which indicates high cultivated land fragmentation. Crucially, high cultivated land fragmentation is not conducive to large-scale cultivated land management and thus affects the area's crop production capacity. Along these lines, the average patch area was small, which hinders biological survival and reproduction; accordingly, species richness in this area was relatively low. Meanwhile, as noted above, patch dimensionality was high, indicating that cultivated land patches were not properly remedied and affected by topographic factors, and the patch edges of cultivated land patches were complex. The patch number, average patch area, and patch density of rural residential and woodland landscapes were not different, but the patch fractal dimension of the rural residential landscape was much smaller than that of the woodland landscape, which indicates that the rural residential landscape was seriously affected by human activity; accordingly, its edge was more regular. Besides, the density index of the wasteland grassland in the unused landscape was high, which indicates that the fragmentation degree of the landscape was also higher and its influence on the surrounding landscape was significant, thereby suggesting that treatment is needed. Meanwhile, the fractal dimensions of the patches in sandy land, bare land, and wasteland were large, which suggests that the patch edge was more complex. Moreover, human activities did not significantly affect the landscape. 
TABLE 1: Current landscape structure of the study area.

\begin{tabular}{|c|c|c|c|c|}
\hline & Landscape type & & Area $\left(\mathrm{hm}^{2}\right)$ & Ratio (\%) \\
\hline \multirow{7}{*}{ Agricultural land landscape } & \multirow{2}{*}{ Cultivated land landscape } & Water irrigated landscape & 691.9296 & 45.44 \\
\hline & & Dryland landscape & 228.8777 & 15.03 \\
\hline & Forestland landscape & & 209.8259 & 13.78 \\
\hline & Landscape & & 44.3930 & 2.92 \\
\hline & Other agricultural land landscape & Farmland road landscape & 38.0402 & 2.50 \\
\hline & & Trench landscape & 30.0666 & 1.97 \\
\hline & & Landscape of farmland shelter & 0.1882 & 0.01 \\
\hline \multirow{2}{*}{ Construction land landscape } & Rural settlements landscape & & 223.7001 & 14.69 \\
\hline & Special land landscape & Funeral land landscape & 1.0948 & 0.07 \\
\hline \multirow{4}{*}{ Other land landscape } & \multirow{4}{*}{ Nature reserve landscape } & Sandy land landscape & 35.7669 & 2.35 \\
\hline & & Naked landscape & 11.8958 & 0.78 \\
\hline & & Tian Kan landscape & 0.0875 & 0.01 \\
\hline & & Grassland landscape & 6.9157 & 0.45 \\
\hline & Total & & $1,522.7820$ & 100.00 \\
\hline
\end{tabular}

TABLE 2: Landscape patch characteristics in the study area.

\begin{tabular}{lcccc}
\hline Landscape type & Number of patches & Average plaque area & Plaque density index & Dimensions \\
\hline Cultivated land & 185 & 5.1811 & 0.19 & 1.065 \\
Garden & 13 & 3.6432 & 0.27 & 0.17 \\
Forestland & 37 & 5.7970 & 0.05 & 1.037 \\
Channels & 1 & 20.5768 & 0.19 & 1.030 \\
Rural settlements & 42 & 5.3677 & 12.15 & 1.048 \\
Funeral and burial sites & 12 & 0.0823 & 0.14 & 1.046 \\
Sandy land & 5 & 7.3155 & 0.17 & 1.176 \\
Bare land & 2 & 5.9126 & 0.71 & 1.126 \\
Grassland & 5 & 1.4053 & 0.20 & 1.112 \\
Total & 302 & 5.0423 & & 1.109 \\
\hline
\end{tabular}

TABle 3: Current landscape diversity indices of the study areas.

\begin{tabular}{lccc}
\hline Maximum diversity index & Shannon index & Evenness index & Advantage index \\
\hline 2.302585 & 1.17324 & 0.509531 & 1.1293 \\
\hline
\end{tabular}

4.1.3. Landscape Diversity Index. According to the maximum landscape diversity index, outlined in Table 3, there were many landscape types in our study area. However, the landscape diversity index was only 1.17324 , which differs from the maximum diversity index. The decrease in the landscape diversity index is due to the large variety of landscape types in our study area. Notably, the landscape evenness index and dominance index were 0.509531 and 1.1293 , respectively, which indicate that the distribution of landscape types is not very uniform, primarily because cultivated land accounts for a large proportion of the landscape.

4.1.4. Corridor Characteristic Index. Table 4 shows that the width of the landscape corridor was uneven, ranging from 0.5 to $13 \mathrm{~m}$. Meanwhile, the density of the corridor was small, the average corridor dimension was high, and the connection degree of the corridor was low. These conditions are not conducive to the use of farmland machinery and the transportation of farmland products. Besides, according to the results of our field investigation, there are only a few farmland shelterbelt corridors in the present study area; ultimately, these cannot form a perfect farmland shelterbelt system.

4.2. Ecological Service Value of the Study Area. Ecosystem service value equivalence of land use types draws on Xie's research results [37]. However, Xie provided the unit price of ecosystem ecological service value under the national average state. The size of ecological service function in different regions is closely related to the biomass of ecosystem. According to the linear relationship between ecosystem service value and biomass in different regions, it is necessary to modify the ecosystem service value before it can be used. According to Mr. Xie's unit price correction formula for ecosystem service value [3], the study area belongs to Hebei Province. After calculation, the correction coefficient (1.02) is obtained, and finally a table of equivalent factors of ecosystem service value suitable for the study area is formed (Table 5), in which cultivated land corresponds to farmland, forest land corresponds to the forest, water area corresponds 
TABLE 4: Current landscape corridor characteristics.

\begin{tabular}{|c|c|c|c|c|c|}
\hline Project landscape type & $\begin{array}{l}\text { Corridor } \\
\text { length }\end{array}$ & $\begin{array}{l}\text { Average corridor } \\
\text { width }\end{array}$ & $\begin{array}{c}\text { Corridor } \\
\text { density }\end{array}$ & $\begin{array}{c}\text { Average corridor } \\
\text { dimension }\end{array}$ & $\begin{array}{c}\text { Corridor } \\
\text { connectivity }\end{array}$ \\
\hline Farmland road landscape & $59,817.63$ & $2-13$ & 39.28 & 1.002 & 0.292 \\
\hline $\begin{array}{l}\text { Irrigation and drainage ditch } \\
\text { landscape }\end{array}$ & $16,292.3$ & $0.5-5$ & 10.70 & 1.003 & 0.186 \\
\hline Landscape of farmland shelter & 3.764 & 0.5 & 2.47 & 1.000 & 1.000 \\
\hline Total & $79,873.93$ & 3.97 & 52.45 & 1.002 & 0.274 \\
\hline
\end{tabular}

TABLE 5: Ecosystem service value per unit area of the ecosystem in the study area (yuan/hm² $\cdot \mathrm{a})$.

\begin{tabular}{|c|c|c|c|c|c|c|}
\hline Function & Farmland & Garden plot & Forestland & Rural construction land & Water surface & Unused land \\
\hline Gas regulation & 451.25 & 1940.50 & 3158.94 & 0.00 & 0.00 & 0.00 \\
\hline Climate change & 803.25 & 1624.61 & 2436.88 & 0.00 & 415.14 & 0.00 \\
\hline Water conservation & 541.52 & 1805.09 & 2888.13 & 27.03 & 18393.86 & 27.03 \\
\hline Soil formation and conservation & 1317.74 & 2639.96 & 3519.92 & 18.05 & 8.98 & 18.05 \\
\hline Waste disposal & 1480.22 & 1182.38 & 1182.38 & 8.98 & 16408.33 & 8.98 \\
\hline Biodiversity conservation & 640.76 & 1963.04 & 2942.29 & 306.82 & 2247.37 & 306.82 \\
\hline Food production & 902.60 & 180.54 & 90.27 & 8.98 & 90.27 & 8.98 \\
\hline Raw materials & 90.27 & 1195.85 & 2346.61 & 0.00 & 8.98 & 0.00 \\
\hline Entertainment culture & 8.98 & 595.68 & 1155.25 & 8.98 & 3917.00 & 8.98 \\
\hline Total & 6236.59 & 13127.66 & 19720.68 & 378.83 & 41489.93 & 378.83 \\
\hline
\end{tabular}

to rivers and lakes, the unit area ecological service value of garden ecosystem takes the average value of grassland and forest land, unused land corresponds to the desert, and rural construction land corresponds to the practice of scholars such as Cai Bangcheng [38]. According to the value of ecological service of desert ecosystem type, hydrological regulation function corresponds to water conservation, and aesthetic landscape corresponds to the ecotourism service function.

Inclusion of pothole is a small land type, which is merged with wetland type in constructed wetlands [38, 39]. However, the total rural roads and ditches in the project area only account for $4 \%$ of the total area of the project area, and the existing ecological service value evaluation methods cannot evaluate the ecological service value of the above land types, so it is omitted.

\subsection{Changes of Landscape Structure in Ecological Landscape Planning}

4.3.1. Adjustment Target of Landscape Ecological Pattern. Land remediation is a process of optimizing the current land use pattern, that is, under the guidance of the theory of landscape ecology, following the principles of protecting and improving the ecological environment and adhering to sustainable development, and taking the adjustment and reconstruction of the spatial structure of landscape units as the basic means, comprehensively adjust the current land landscape pattern in the study area, layout roads, drainage and irrigation networks, crops, farmland structure Shelterbelt system, and land unit, build a harmonious spatial structure and stable ecosystem, so as to form a coordinated landscape of "farmland rules, trees, ditches, and production roads," and realize the goal of sustainable utilization of land resources.

4.3.2. Contents of Landscape Ecological Pattern Adjustment in the Study Area. To maintain the ecological diversity of the study area, a certain type of patches in the study area were retained when the ecological pattern of the land landscape was adjusted [40] (Table 6). First of all, we consider preserving $181.7828 \mathrm{hm}^{2}$ with high ecological value landscape of natural, artificial, or ecological woodlands, $20,5757 \mathrm{hm}^{2}$ ecological ditch landscape, unsuitable $3.3029 \mathrm{hm}^{2}$ sandy landscape, $0.7820 \mathrm{hm}^{2}$ bare landscape, and $0.2322 \mathrm{hm}^{2}$ barren landscape near the ditch. Secondly, the scattered distribution of landscape fragmentation in the study area was $0.5256 \mathrm{hm} 2$ inside the cultivated land Funeral Land Landscape $1.6206 \mathrm{hm} 2$ Rural settlements landscape, $1.8737 \mathrm{hm} 2$ Ditch landscape and $4.3319 \mathrm{hm} 2$ Garden landscape is transformed into the cultivated land landscape, and the ecological benefit is not high $28.0431 \mathrm{hm} 2$ Forest land landscape adjusted to cultivated land landscape, will $10.9058 \mathrm{hm} 2$ Sandy landscape, $3.2951 \mathrm{hm} 2$ Bare landscape and $1.8551 \mathrm{hm} 2$ The landscape of wasteland is developed as cultivated land landscape. Thirdly, to strengthen the ecological environment protection and improve the ecological value of land landscape in the study area will be made on Sandy Land Landscape, $4.8284 \mathrm{hm} 2$ Grassland landscape and $7.6165 \mathrm{hm} 2$ The bare land landscape is adjusted to the woodland landscape. Based on making full use of the existing landscape corridors, $34.1695 \mathrm{hm} 2$ are planned around the cultivated land landscape patches to improve the productivity of farmland landscape ecosystem Farmland Road Landscape, $28.1929 \mathrm{hm} 2$ Drainage ditch landscape, $4.0415 \mathrm{hm} 2$ Farmland shelterbelt landscape. 
TABLE 6: Landscape structure comparison before and after planning.

\begin{tabular}{|c|c|c|c|c|c|c|c|c|}
\hline & Land classes & & $\begin{array}{l}\text { Prior period } \\
\quad\left(\mathrm{hm}^{2}\right)\end{array}$ & $\begin{array}{l}\text { Percentage } \\
(\%)\end{array}$ & $\begin{array}{l}\text { Regulation } \\
\left(\mathrm{hm}^{2}\right)\end{array}$ & $\begin{array}{c}\text { Percentage } \\
(\%)\end{array}$ & $\begin{array}{c}\text { Increase or } \\
\text { decrease } \\
\left(\mathrm{hm}^{2}\right)\end{array}$ & Percentage (\%) \\
\hline \multirow{8}{*}{ Agricultural land } & \multirow[t]{2}{*}{$\begin{array}{l}\text { Cultivated } \\
\text { land }\end{array}$} & $\begin{array}{l}\text { Water } \\
\text { irrigated } \\
\text { land }\end{array}$ & 691.9296 & 45.44 & 973.2583 & 63.91 & 281.3287 & 18.47 \\
\hline & & Drylands & 228.8777 & 15.03 & 0.0000 & 0.00 & -228.8777 & -15.03 \\
\hline & \multirow{2}{*}{$\begin{array}{l}\text { Subtotal } \\
\text { Garden }\end{array}$} & \multirow[t]{3}{*}{920.8073} & 60.47 & 973.2583 & 63.91 & 52.4510 & 3.44 & \\
\hline & & & 44.3930 & 2.92 & 40.6031 & 2.67 & -3.7899 & -0.25 \\
\hline & Forestland & & 209.8259 & 13.78 & 213.4238 & 14.02 & 3.5979 & 0.24 \\
\hline & \multirow{3}{*}{$\begin{array}{c}\text { Other } \\
\text { agricultural } \\
\text { land }\end{array}$} & \multirow{5}{*}{$\begin{array}{l}\text { Farmland } \\
\text { roads } \\
\text { Channels } \\
\text { Farmland } \\
\text { shelter }\end{array}$} & 38.0402 & 2.50 & 41.3922 & 2.72 & 3.3520 & 0.22 \\
\hline & & & 30.0666 & 1.97 & 28.1929 & 1.85 & -1.8737 & -0.12 \\
\hline & & & 0.1882 & 0.01 & 4.0415 & 0.27 & 3.8533 & 0.25 \\
\hline \multirow[b]{2}{*}{ Total } & \multirow[t]{2}{*}{ Subtotal } & & 68.2950 & 4.48 & 73.6266 & 4.84 & 5.3316 & 0.35 \\
\hline & & & 1243.3212 & 81.65 & 1300.9117 & 85.43 & 57.5905 & 3.78 \\
\hline \multirow{5}{*}{ Construction land } & \multirow{5}{*}{$\begin{array}{c}\text { Rural } \\
\text { settlements } \\
\text { Subtotal } \\
\text { Special land } \\
\text { use } \\
\text { Subtotal }\end{array}$} & \multirow{5}{*}{$\begin{array}{l}\text { Funeral and } \\
\text { burial sites }\end{array}$} & 223.7001 & 14.69 & 217.1249 & 14.26 & -6.5752 & -0.43 \\
\hline & & & 223.7001 & 14.69 & 217.1249 & 14.26 & -6.5752 & -0.43 \\
\hline & & & 1.0948 & 0.07 & 0.3408 & 0.02 & -0.7540 & -0.05 \\
\hline & & & 1.0948 & 0.07 & 0.3408 & 0.02 & -0.7540 & -0.05 \\
\hline & & & 224.7949 & 14.76 & 217.4657 & 14.28 & -7.3292 & -0.48 \\
\hline \multirow{5}{*}{ Other land } & \multirow{4}{*}{$\begin{array}{l}\text { Natural } \\
\text { reserves }\end{array}$} & Sandy land & 35.7669 & 2.35 & 3.3029 & 0.22 & -32.4640 & -2.13 \\
\hline & & Bare land & 11.8958 & 0.78 & 0.7820 & 0.05 & -11.1138 & -0.73 \\
\hline & & Tian Kan & 0.0875 & 0.01 & 0.0875 & 0.01 & 0.0000 & 0.00 \\
\hline & & Grassland & 6.9157 & 0.45 & 0.2322 & 0.02 & -6.6835 & -0.44 \\
\hline & \multirow[t]{2}{*}{ Subtotal } & & 54.6659 & 3.59 & 4.4046 & 0.29 & -50.2613 & -3.30 \\
\hline Total & & & 54.6659 & 3.59 & 4.4046 & 0.29 & -50.2613 & -3.30 \\
\hline Total land area & & & 1522.7820 & 100.00 & 1522.7820 & 100.00 & 0.0000 & 0.00 \\
\hline
\end{tabular}

TABLE 7: Index of plaque characteristics after treatment.

\begin{tabular}{|c|c|c|c|c|c|c|c|c|}
\hline \multirow[b]{2}{*}{ Landscape type } & \multicolumn{2}{|c|}{ Number of patches } & \multicolumn{2}{|c|}{ Average patch area $\left(\mathrm{hm}^{2}\right)$} & \multicolumn{2}{|c|}{ Plaque density index } & \multicolumn{2}{|c|}{ Dimensions } \\
\hline & $\begin{array}{c}\text { Traditional } \\
\text { traditions } \\
\text { planning }\end{array}$ & $\begin{array}{c}\text { Landscape } \\
\text { state } \\
\text { planning }\end{array}$ & $\begin{array}{c}\text { Traditional } \\
\text { traditions } \\
\text { planning }\end{array}$ & $\begin{array}{c}\text { Landscape } \\
\text { state } \\
\text { planning }\end{array}$ & $\begin{array}{c}\text { Traditional } \\
\text { traditions } \\
\text { planning }\end{array}$ & $\begin{array}{c}\text { Landscape state } \\
\text { planning }\end{array}$ & $\begin{array}{c}\text { Traditional } \\
\text { traditions } \\
\text { planning }\end{array}$ & $\begin{array}{c}\text { Landscape } \\
\text { state } \\
\text { planning }\end{array}$ \\
\hline Cultivated land & 152 & 139 & 7.3682 & 7.2724 & 0.14 & 0.14 & 1.033 & 1.030 \\
\hline Garden & 10 & 10 & 2.4833 & 4.2163 & 0.40 & 0.24 & 1.054 & 1.049 \\
\hline Forestland & 23 & 30 & 5.5631 & 7.3688 & 0.18 & 0.14 & 1.127 & 1.142 \\
\hline Channels & 1 & 1 & 20.5768 & 20.5768 & 0.05 & 0.05 & 1.025 & 1.025 \\
\hline $\begin{array}{l}\text { Rural } \\
\text { settlements }\end{array}$ & 42 & 37 & 5.3677 & 6.0462 & 0.19 & 0.17 & 1.048 & 1.046 \\
\hline $\begin{array}{l}\text { Funeral and } \\
\text { burial sites }\end{array}$ & 12 & 3 & 0.0823 & 0.1213 & 12.15 & 8.24 & 1.046 & 1.032 \\
\hline Sandy land & 5 & 5 & 0.6047 & 0.6047 & 1.65 & 1.65 & 1.087 & 1.087 \\
\hline Bare land & 0 & 1 & - & 0.7904 & - & 1.27 & - & 1.018 \\
\hline Grassland & 0 & 1 & - & 0.2326 & - & 4.30 & - & 1.013 \\
\hline Total & 245 & 227 & 6.2154 & 6.7083 & 0.16 & 0.15 & 1.048 & 1.048 \\
\hline
\end{tabular}

\subsection{Comparative Analysis of Traditional Planning and Landscape Ecological Planning Landscape Pattern Index}

4.4.1. Plaque Characteristic Index. Comparing Table 7 with the present patch characteristic index table reveals that the land in the study area changed greatly after the traditional planning and design and landscape ecological planning and design. Compared with the present situation, the number of patches reduced, the average patch area improved, and the patch density decreased significantly, indicating that both schemes made some progress toward reducing landscape fragmentation and increasing land scale management and farmland crop yield. Across these two kinds of planning, the number of patches was lower, the average patch area slightly higher, and the patch density lower in landscape ecological planning than in traditional planning, which indicates that 
TABLE 8: Index of landscape diversity after the study area regulation.

\begin{tabular}{lccccccc}
\hline \multicolumn{2}{c}{ Maximum diversity index } & \multicolumn{2}{c}{ Shannon index } & \multicolumn{2}{c}{ Evenness index } & \multicolumn{2}{c}{ Advantage index } \\
$\begin{array}{l}\text { Traditional } \\
\text { planning }\end{array}$ & $\begin{array}{c}\text { Landscape } \\
\text { ecological } \\
\text { planning }\end{array}$ & $\begin{array}{c}\text { Traditional } \\
\text { planning }\end{array}$ & $\begin{array}{c}\text { Landscape } \\
\text { ecological } \\
\text { planning }\end{array}$ & $\begin{array}{c}\text { Traditional } \\
\text { planning }\end{array}$ & $\begin{array}{c}\text { Landscape } \\
\text { ecological } \\
\text { planning }\end{array}$ & $\begin{array}{c}\text { Traditional } \\
\text { planning }\end{array}$ & $\begin{array}{c}\text { Landscape } \\
\text { planning } \\
\text { planical }\end{array}$ \\
\hline 1.945910 & 2.197225 & 0.85970 & 1.01217 & 0.441796 & 0.460657 & 1.0862 & 1.1851 \\
\hline
\end{tabular}

landscape ecological planning more effectively reduces landscape fragmentation. Meanwhile, after the implementation of the two planning approaches, the fractal dimension of cultivated land patches also decreased to 1.033 and 1.030, respectively, indicating that landscape ecological planning carried out more appropriate remediation activities on cultivated land and reduced more effectively the edge complexity of cultivated land patches than traditional planning. Besides, after the implementation of the two planning and design approaches, the number of patches also declined; in traditional planning and design, bare land and wasteland were developed into cultivated land; meanwhile, in landscape ecological planning and design, certain amounts of unsuitable bare land and wasteland were retained to maintain landscape diversity and ensure the survival and reproduction of local organisms.

The above analysis suggests that these two approaches to land regulation planning and design greatly influenced the landscape pattern of the study area; in particular, they tended to simplify its land types, regularize the patch shape, and increase the average patch area. Ultimately, landscape planning and design proved more effective than traditional design.

4.4.2. Landscape Diversity Index. Compared with the present landscape diversity index of the study area [41] (Table 8), the land landscape Shannon index of the study area before and after the renovation demonstrated the following rank: current landscape $>$ landscape ecological planning $>$ traditional planning. However, landscape ecological planning still proved beneficial for protecting the landscape's diversity and, compared with traditional planning, more effective for restraining the uneven trend of land type distribution bias, which encourages sustainable development.

4.4.3. Corridor Characteristic Index. After the planning and designing of the land pattern in the study area [42], the landscape corridor added roads, irrigation, drainage ditches, and farmland shelterbelts, thereby forming a perfect system. After planning and designing, the road corridors in the study area were divided into two types: field and production roads. The length and density of the corridor increased (Table 9). After planning, the roads in the study area were staggered, forming a network; the average corridor dimension was reduced, and the corridor connection improved. Compared with the lack of a complete shelterbelt system in the study area before planning, the planned farmland shelterbelt combined with the field road layout increased the density and formed a perfect farmland shelterbelt system.
Compared with traditional planning, the corridor length, density, and connection degree were higher, but the average corridor width was slightly lower, which indicates that landscape ecological planning pays more attention to the protection of the landscape ecology in the study area based on improving the corridor connection degree and is more reasonable for the corridor design.

4.5. Comparative Analysis of the Value and Benefit of Ecological Services before and after Traditional Planning and Landscape Ecological Planning. By quantitatively estimating the value of ecological services before and after land regulation, the amount of increase or decrease in ecological service value brought by land regulation can be determined, and the ecological benefit of land regulation can be quantitatively evaluated and calculated. The ecological value of the traditional planning scheme and the landscape ecological planning scheme in the study area are shown in Table 10.

Our ecological value calculation shows that, according to the landscape ecology planning method, the land renovation project offers more significant benefits to our ecological environment than the traditional planning method, especially with improving and intensifying land use. It is important to note that the total ecological service value of Dongwang Township before the land renovation was 10.5693 million yuan and the renovation reduced this value to 9.7214 million yuan. The reduction rate (percentage of the ratio of ecological service value reduction to the total ecological service value before regulation) was $8.02 \%$. In terms of ecosystem service value of various types of land after renovation, cultivated land increased by 945000 yuan, garden land decreased by 295700 yuan, forest land decreased by 1477600 yuan, and unused land decreased by 19500 yuan. Land for rural construction and water use remained unchanged.

After the renovation following landscape ecology principles, the value of the total ecological services increased to 10.9853 million yuan, which represented an increased rate of 3.94. After remediation, the values of the ecosystem services of cultivated land, forest land, and unused land increased by 327,100 yuan (this was 617,900 yuan less than the traditional planning scheme), 71,000 yuan (this was 1.5485 million yuan more than the traditional planning scheme), and 71,000 yuan (this was 90,000 yuan more than the traditional planning scheme), respectively, while those of garden land and rural construction land decreased by 49,800 yuan (this was 246,000 yuan more than the traditional planning scheme) and 2,800 yuan (this was 100 yuan more than the traditional planning scheme), respectively; the value of water 


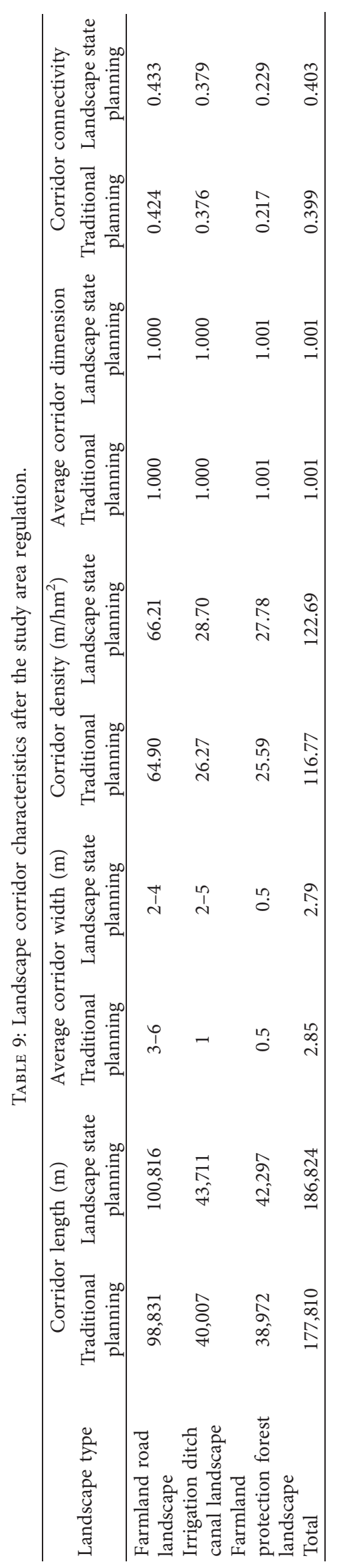


TABLE 10: Comparison of the ecological values of the traditional planning scheme and the landscape ecological planning scheme (yuan, \%).

\begin{tabular}{|c|c|c|c|c|c|c|}
\hline \multirow[t]{2}{*}{ Land classes } & \multicolumn{2}{|c|}{ Prior period } & \multicolumn{2}{|c|}{$\begin{array}{l}\text { Traditional planning } \\
\text { methodology }\end{array}$} & \multicolumn{2}{|c|}{$\begin{array}{c}\text { Landscape ecological } \\
\text { planning }\end{array}$} \\
\hline & Output & Percentage & Output & Percentage & Output & Percentage \\
\hline Cultivated land & $5,742,698$ & 54.33 & $6,687,683$ & 68.79 & $6,069,813$ & 55.25 \\
\hline Garden & 582,776 & 5.51 & 287,035 & 2.95 & 533,023 & 4.85 \\
\hline Forestland & $4,137,907$ & 39.15 & $2,660,334$ & 27.37 & $4,208,860$ & 38.31 \\
\hline Rural construction land & 85,161 & 0.81 & 85,159 & 0.88 & 82,385 & 0.75 \\
\hline Water surface & 0 & 0.00 & 0 & 0.00 & 0 & 0.00 \\
\hline Unused land & 20,710 & 0.20 & 1,182 & 0.01 & 91,218 & 0.83 \\
\hline Total & $10,569,252$ & 100.00 & $9,721,393$ & 100.00 & $10,985,299$ & 100.00 \\
\hline
\end{tabular}

TABLE 11: Comparison of the value changes of the individual ecological services of land in the study area (yuan, \%).

\begin{tabular}{|c|c|c|c|c|c|c|c|c|c|c|}
\hline Function & $\begin{array}{l}\text { Prior } \\
\text { period } \\
\text { output }\end{array}$ & Percentage & $\begin{array}{l}\text { Traditional } \\
\text { regulations } \\
\text { program } \\
\text { output }\end{array}$ & Percentage & $\begin{array}{l}\text { Landscape } \\
\text { state } \\
\text { planning } \\
\text { output }\end{array}$ & Percentage & $\begin{array}{l}\text { Traditional } \\
\text { mention } \\
\text { high value } \\
\text { change }\end{array}$ & $\begin{array}{l}\text { Rate of } \\
\text { change }\end{array}$ & $\begin{array}{l}\text { Landscape } \\
\text { increase } \\
\text { change }\end{array}$ & $\begin{array}{l}\text { Rate of } \\
\text { change }\end{array}$ \\
\hline Gas regulation & $1,164,486$ & 11.02 & 952,462 & 9.80 & $1,192,166$ & 10.85 & $-212,025$ & -18.21 & 27,680 & 2.38 \\
\hline Climate change & $1,323,080$ & 12.52 & $1,225,608$ & 12.61 & $1,367,822$ & 12.45 & $-97,472$ & -7.37 & 44,742 & 3.38 \\
\hline $\begin{array}{l}\text { Water } \\
\text { conservation }\end{array}$ & $1,192,327$ & 11.28 & $1,015,928$ & 10.45 & $1,229,113$ & 11.19 & $-176,399$ & -14.79 & 36,786 & 3.09 \\
\hline $\begin{array}{l}\text { Soil formation } \\
\text { Protection }\end{array}$ & $2,074,195$ & 19.62 & $1,949,728$ & 20.06 & $2,149,198$ & 19.56 & $-124,467$ & -6.00 & 75,003 & 3.62 \\
\hline Waste disposal & $1,666,090$ & 15.76 & $1,774,688$ & 18.26 & $1,745,108$ & 15.89 & 108,597 & 6.52 & 79,018 & 4.74 \\
\hline $\begin{array}{l}\text { Biological } \\
\text { diversity } \\
\text { Sexual } \\
\text { protection }\end{array}$ & $1,380,275$ & 13.06 & $1,196,874$ & 12.31 & $1,471,885$ & 13.40 & $-183,400$ & -13.29 & 91,610 & 6.64 \\
\hline $\begin{array}{l}\text { Food } \\
\text { production }\end{array}$ & 860,586 & 8.14 & 986,057 & 10.14 & 909,174 & 8.28 & 125,471 & 14.58 & 48,588 & 5.65 \\
\hline Raw materials & 628,588 & 5.95 & 439,506 & 4.52 & 637,234 & 5.80 & $-189,082$ & -30.08 & 8,645 & 1.38 \\
\hline $\begin{array}{l}\text { Entertainment } \\
\text { culture }\end{array}$ & 279,624 & 2.65 & 180,545 & 1.86 & 283,599 & 2.58 & $-99,079$ & -35.43 & 3,975 & 1.42 \\
\hline Total & $10,569,252$ & 100.00 & $9,721,393$ & 100.00 & $10,985,299$ & 100.00 & $-847,858$ & -8.02 & 416,047 & 3.94 \\
\hline
\end{tabular}

remained the same. Meanwhile, the single land service value function (Table 11) demonstrates that the soil formation and protection value function were the highest before remediation, accounting for approximately $20 \%$ of the total service value of the study area. The entertainment cultural function was the smallest, accounting for approximately $2 \%$ of the value of regional services.

The traditional plan reduced the value of single services, with the exceptions of the waste treatment and food production; most notable is the function of entertainment culture, which was under the aim of the traditional land renovation of increasing grain production, but neglected the comprehensive service value of the land. Conversely, the landscape ecological planning scheme improved the value function of every single ecological service. The highest increase rate was in the biodiversity protection function, which reached 6.64; the smallest increase was in the entertainment cultural service function [43]. These results could be attributed to the increases in woodland, which offset the value of individual services lost by reducing cultivated land. A comparison of the traditional and landscape ecology planning schemes reveals that the latter can improve the area's comprehensive service function value, prevent the simple pursuit of grain production, and realize the modern land regulation goals of protecting biodiversity and improving rural ecological service functions and landscape value through natural resource protection [44], the biological restoration of the ecological environment, nonpoint source pollution control, and the construction of ecological networks and green infrastructure [45].

\section{Conclusions}

In this study, we conducted a comparative analysis of the landscape pattern status, traditional landscape pattern planning results, and ecological landscape planning results of Quyang County using the landscape pattern index and the calculation results of ecological service value to assess best practices for land regulation planning in the study area. The results are as follows:

(1) The average patch area in the landscape ecology planning and design scheme was higher than that of the traditional planning scheme; meanwhile, the number and density of patches in the landscape ecology scheme were lower than in the traditional 
planning scheme, which indicates that the landscape ecology planning scheme can effectively reduce landscape fragmentation and intensify its management. Notably, the hierarchy of the landscape approaches according to the Shannon index is as follows: current landscape >landscape ecological planning > traditional planning; landscape ecological planning was most conducive to the protection of the now-declining diversity of the landscape.

(2) Landscape ecological planning offered better outcomes than traditional planning in terms of corridor length, density, and connectivity, although it slightly lowered the average corridor width, which indicates that more attention is paid to the protection of landscape ecology in the study area based on increasing corridor connectivity and that the corridor design is more reasonable.

(3) Landscape ecological planning can improve ecological service values in the study area to varying degrees and thus discourages the simple pursuit of grain production; ultimately, this brings the area closer in line with modern approaches to comprehensive land regulation.

\section{Data Availability}

The data used to support the findings of this study are available from the corresponding author upon request.

\section{Conflicts of Interest}

The authors declare that they have no conflicts of interest.

\section{Authors' Contributions}

Yin Haikui and Yapeng Zhou contributed equally to this work.

\section{Acknowledgments}

The research was supported by the Research Topics of Social Science Development in Hebei Province (201903120415).

\section{References}

[1] J. Yang, A. Guo, Y. Li, Y. Zhang, and X. Li, "Simulation of landscape spatial layout evolution in rural-urban fringe areas: a case study of Ganjingzi district," GIScience \& Remote Sensing, vol. 56, no. 3, pp. 388-405, 2019.

[2] Y. Zhu and C. Pu, "Analysis of land use landscape pattern change and ecological security in Urumqi city," Ecological Science, vol. 39, no. 2, pp. 133-144, 2020.

[3] S. Pauleit and R. G. Y. Ennos, "Modeling the environmental impacts of urban land use and land cover change-a study in Merseyside, UK," Landscape and Urban Planning, no. 71, pp. 295-310, 2005.

[4] R. Tan and R. Wang, "Building on German rural renovation experience to promote comprehensive land renovation in area Zhejiang," Land and Resources, vol. 10, pp. 19-22, 2018.
[5] L. Josip, "Croatian LADM profile extension for state-owned agricultural land management," Land, vol. 10, no. 2, p. 222, 2021.

[6] Z. Guo, J. Gao, P. Sun et al., "Influence of gully land consolidation on phreatic water transformation in the loess hilly and gully region,” Water, vol. 13, no. 4, p. 538, 2021.

[7] K. P. Jelena, R. Katarina, and J. Nikša, "Assessing the bonitet of cadastral parcels for land reallocation in urban consolidation," Land, vol. 10, no. 1, p. 9, 2020.

[8] Z. Liang, History of Land Management in China, Tianjin People's Publishing House, Tianjin, China, 1996.

[9] Y. Zhang, "The contribution of Fintech to sustainable development in the digital age: ant forest and land restoration in China," Land Use Policy, vol. 103, 2021.

[10] H. Guo, "Study on the delimitation of the "three lines" of land use planning in hilly and mountainous areas," Chongqing Institute of Land Resources and Housing Survey and Planning, 2018.

[11] $\mathrm{Mu} \mathrm{Xu,} \mathrm{Land} \mathrm{Management} \mathrm{and} \mathrm{Utilization} \mathrm{in} \mathrm{China} \mathrm{Beijing,}$ China Agricultural Science Press, Beijing, China, 1995.

[12] M. Poku-Boansi, "Multi-stakeholder involvement in urban land use planning in the Ejisu municipality, Ghana: an application of the social complexities' theory," Land Use Policy, vol. 103, 2021.

[13] Z. Zhang, Research on Revision of Planning and Design Specifications for Land Development and Consolidation Projects, Land Consolidation Center, Ministry of Land and Resources, Beijing, China, 2011.

[14] Y. Xiao, Landscape Ecological Security and Sustainability Evaluation of Typical Farm Land Consolidation in Sanjiang Plain, China University of Geosciences, Beijing, China), 2017.

[15] X. Zeng and X. Hu, "Study on comprehensive benefit evaluation of land consolidation project-a case study of land consolidation project in Jingbian county," Agriculture and Technology, vol. 40, no. 15, pp. 165-166, 2020.

[16] S. Sun, J. Cui, and Y. Liu, "Ecological value evaluation of land consolidation," Regional Governance, no. 38, pp. 3840, 2019.

[17] R. Yonaba, "Spatial and transient modelling of land use/land cover (LULC) dynamics in a Sahelian landscape under semiarid climate in northern Burkina Faso," Land Use Policy, vol. 103, 2021.

[18] A. Guo, J. Yang, W. Sun et al., "Impact of urban morphology and landscape characteristics on spatiotemporal heterogeneity of land surface temperature," Sustainable Cities and Society, vol. 63, Article ID 102443, 2020.

[19] I. L. Mc Harg, Design with Nature, Doubleday, Garden City, NY, USA, 1969.

[20] E. P. Odum, "The strategy of ecosystem development," Science, vol. 164, no. 3877, pp. 262-270, 1969.

[21] W. Haber, "Using landscape ecology in planning and management," in Changing Landscapes: an Ecological Perspective, I. S. Zonneveld and R. T. T. Forman, Eds., Springer-Verlag, NewYork, NY, USA, pp. 217-232, 1990.

[22] A. Farina, "Introduction to landscape ecology," Principles and Methods in Landscape Ecology, Chapman \& Hall, London, UK, pp. 1-21, 1998.

[23] L. Smalling Kelly, "Environmental and anthropogenic drivers of contaminants in agricultural watersheds with implications for land management," Science of the Total Environment, vol. 774, 2021.

[24] J. Zhang, T. Zhang, and B. Wang, "Development and prospect of landscape ecology," Research Forestry Survey and Design, no. 2, pp. 26-28, 2008. 
[25] X. Huang, Ecological Status and Protection of the Federal Republic of Germany, Geography, 1981.

[26] A. Liu, A Study on Landscape Ecology in Czechoslovakia, Geography, 1981.

[27] L. Qi, "Current research status of landscape ecology at home and abroad science," Technology and Innovation, no. 9, pp. 145-146, 2020.

[28] V. Whitford, A. R. Ennos, and J. F. Handley, "City form and natural process indicators for the ecological performance of urban areas and their application to Merseyside, UK," Landscape and Urban Planning, vol. 57, no. 2, pp. 91-103, 2001.

[29] G. Xian, M. Crane, and J. Su, “An analysis of urban development and its environmental impact on the Tampa Bay watershed," Journal of Environmental Management, vol. 85, no. 4, pp. 965-976, 2007.

[30] J. Yang, Y. Wang, C. Xiu, X. Xiao, J. Xia, and C. Jin, "Optimizing local climate zones to mitigate urban heat island effect in human settlements," Journal of Cleaner Production, vol. 275, Article ID 123767, 2020.

[31] Urban Research, "Urban planning; study findings from Chinese academy of sciences broaden understanding of urban planning (evaluation of the environmental effects of intensive land consolidation: a field-based case study of the Chinese Loess plateau)," Food \& Farm Week, 2020.

[32] H. Jin, "Analysis of land planning and utilization in land resource management in China," Journal of Social Science and Humanities, vol. 2, no. 3, 2020.

[33] X. Zhang, "Study on land consolidation and rural ecological environment protection," Science and Technology Economy Guide, vol. 28, no. 13, p. 86, 2020.

[34] J. Yang, X. Luo, C. Jin, X. Xiao, and J. Xia, "Spatiotemporal patterns of vegetation phenology along the urban-rural gradient in coastal Dalian, China," Urban Forestry \& Urban Greening, vol. 54, Article ID 126784, 2020.

[35] G. Liu, "Current situation and assumption of agricultural and rural economic development in Fuping county, Hebei province," Modern Rural Science and Technology, no. 3, pp. 4-6, 2011.

[36] R. Costanza, R. D'arge, R. de Groot et al., "The value of the world's ecosystem services and natural capital," Nature, vol. 387, no. 6630, pp. 253-260, 1997.

[37] G. Xie, C. Lua, and Y. Leng, "Evaluation on the value of ecological assets in Qinghai-tibet plateau," Journal of Natural Resources, vol. 18, no. 2, pp. 189-196, 2003.

[38] C. Bangcheng, L. Genfa, and C. Xiaojun, "Application of ecosystem service value evaluation in land use evaluation in Nanjing," Environmental Protection Nursing Science, vol. 33, no. 4, pp. 104-110, 2007.

[39] L. Jiang and M. Du, "Landscape ecological risk assessment of Nong'an county based on ecosystem services," Environmental Ecology, vol. 1, no. 3, pp. 39-45, 2019.

[40] J. Shi, Research on Planning and Design of Land Consolidation Project in Piedmont Plain of Taihang Mountain Based on Landscape Ecology, Hebei Agricultural University, Baoding, China, 2012.

[41] C. Lian, Study on Ecological Land Consolidation Planning and Design in Southwest Hilly Area, Southwest University, El Paso, TX, USA, 2014.

[42] L. Su, Analysis on the Evolution of Land Use Landscape Pattern under the Background of Comprehensive Land Improvement, Chengdu University of Technology, Chengdu, China, 2019.
[43] M. Luo, Z. Yu, and L. Ying, "Comprehensive land renovation from the perspective of ecosystem health," Land in China, no. 2, pp. 4-8, 2020.

[44] W. L. Shang, H. Bi, Y. Chen, and W. Ochieng, "Statistical characteristics and community analysis of urban road networks," Complexity, vol. 2020, Article ID 6025821, 21 pages, 2020.

[45] L. Liu, J. Liu, Z. Liu, X. Xu, and B. Wang, "Analysis on the spatio-temporal characteristics of urban expansion and the complex driving mechanism: taking the pearl river delta urban agglomeration as a case," Complexity, vol. 2020, Article ID 8157143, 12 pages, 2020. 